\title{
Sorption Characteristics of Cr(III) onto Florisil: Kinetics, Thermodynamics and Equilibrium Studies
}

\author{
Aslı Erdem Yayayürük*, Onur Yayayürük \\ Department of Chemistry, Faculty of Science, Ege University, 35100 Bornova, Izmir, Turkey \\ Tel. +902323112389 / Fax: +90232388 8264 \\ aslierdem30@hotmail.com \\ *Corresponding author.
}

Received: 3 March 2017

Accepted: 21 May 2017

DOI: $10.18466 /$ cbayarfbe.339318

\begin{abstract}
In this study, the efficiency of florisil was investigated for the removal of $\mathrm{Cr}$ (III) using batch type sorption under different experimental conditions namely $\mathrm{pH}$, sorbent amount, contact time and temperature. The maximum sorption capacity of florisil for $\mathrm{Cr}$ (III) ions was determined as $67.5 \mathrm{mg} \mathrm{g}^{-1}$, at $\mathrm{pH} 6.0$, with a contact time of 60.0 minutes at $25^{\circ} \mathrm{C}$. The equilibrium kinetics, isotherms, and thermodynamics of $\mathrm{Cr}$ (III) ion sorption onto florisil were also studied and it was evaluated that the sorption kinetics of $\operatorname{Cr}(\mathrm{III})$ on florisil followed pseudo-second-order model. The equilibrium data were in good agreement with the Langmuir isotherm model indicating monolayer coverage on the sorbent surface. In addition, thermodynamic studies revealed that the sorption of Cr(III) onto florisil was spontaneous and exothermic. The presented method was applied to the determination of $\mathrm{Cr}(\mathrm{III})$ in ultra-pure, tap, bottled drinking and waste water samples and high recoveries obtained confirmed the accuracy of the proposed study. The overall results have demonstrated that florisil is a promising and efficient sorbent and a good candidate for the removal of $\mathrm{Cr}(\mathrm{III})$ from aqueous solutions.
\end{abstract}

Keywords - Chromium, Sorption, Inductively Coupled Plasma Mass Spectrometry, Florisil.

\begin{abstract}
1 Introduction
Environmental pollution caused by Chromium (Cr) has become a serious threat to human beings in recent years [1]. Chromium originates both from natural sources and human activities like wood preserving, electroplating, leather tanning, porcelain and ceramics manufacturing, photoengraving and alloy production etc [2]. It may contaminate environmental waters and enter human body through intake of water, penetrate biological membranes and cause serious health problems [3]. According to the United States Environmental Protection Agency, the maximum acceptable concentration for total chromium in drinking water is $100 \mu \mathrm{g} \mathrm{L}^{-1}$ and a stricter threshold limit (50 $\mu \mathrm{g} \mathrm{L^{-1 }}$ ) has been set by the World Health Organization and China [4]. Chromium exists in several oxidation states, but the most predominant forms are $\mathrm{Cr}(\mathrm{III})$ and $\mathrm{Cr}(\mathrm{VI})$ in aquatic systems [5].
\end{abstract}

$\mathrm{Cr}(\mathrm{VI})$ is considered to be a priority pollutant and has a definitely adverse impact on living organisms. It is toxic to both plants and animals as well as may cause several diseases like liver, kidney, lung and gastrointestinal cancers [6]. Although $\mathrm{Cr}$ (III) is an essential to mammals for the maintenance of glucose, protein and lipid metabolism, it is also a potential hazard especially in aquatic environment [1]. Thus it becomes very necessary to remove chromium from waters before it releases into the environment.

Several methods have been developed for the removal, determination and preconcentration of chromium from waters including membrane separation [1], coagulation [7], ion exchange [8], adsorption [9], extraction [10] and precipitation [11]. Among these methods, adsorption can be regarded as one of the most promising methods for removal of toxic metals from the aqueous solutions due to its flexibility, simplicity, high efficiency and relatively low cost. Generally, an ideal adsorbent should offer a stable matrix with abundant binding sites which is suitable for adsorption of heavy metal ions [12]. Florisil ${ }^{\circledR}$ is an inorganic support that reveals high resistance to chemical, thermal and radiation degradation and it was recently used in several studies due to its crystalline and well-ordered periodic pore structure $[13,14]$. In the present study, Florisil ${ }^{\circledR}$ was proposed for the batch removal of $\mathrm{Cr}$ (III) ions from the aqueous solutions and the optimum parameters such as $\mathrm{pH}$, sorption time, sorbent amount and sorbent capacity were determined. Moreover sorption kinetics and equilibrium isotherms of the sorption of $\mathrm{Cr}(\mathrm{III})$ ions were also elucidated. 


\section{Experimental}

\subsection{Material and Methods}

All reagents and chemicals were of analytical grade. Ultrapure water $(18.2 \mathrm{M} \Omega)$ was used throughout the study. Glassware and plastic ware were cleaned by soaking in $10 \%(\mathrm{v} / \mathrm{v})$ nitric acid and rinsed with ultrapure water prior to use. Standard (1000 $\left.\mathrm{mg} \mathrm{L}^{-1}\right) \operatorname{Cr}(\mathrm{III})$ and $\mathrm{Cr}(\mathrm{VI})$ stock solutions were prepared from by dissolving appropriate amount of chromium(III) nitrate, $\mathrm{Cr}\left(\mathrm{NO}_{3}\right)_{3}$ and potassium dichromate, $\mathrm{K}_{2} \mathrm{Cr}_{2} \mathrm{O}_{7}$ in $2 \mathrm{~mol} \mathrm{~L}^{-1} \mathrm{HNO}_{3}$, respectively. Lower concentration standards were prepared daily from their stock standard solutions. Florisil $^{\circledR}$ (magnesium silicate, particle size 150-250 $\mu \mathrm{m}$, pore size $6-8 \mathrm{~nm}$ and surface area $170-300 \mathrm{~m}^{2} / \mathrm{g}$ ) was purchased from Merck (Darmstadt, Germany). Chromium analysis $(\mathrm{m} / \mathrm{z}=52$, natural abundance of \%83.79) was made by an inductively coupled plasma mass spectrometer (ICP-MS). The Agilent 7700 (Tokyo, Japan) type ICP-MS instrument was equipped with a high solid nebulizer, a Peltier-cooled spray chamber $\left(2^{\circ} \mathrm{C}\right)$, and an octopole collision/reaction cell with hydrogen gas pressurization (purity of 99.999\%). The ICP-MS operating conditions can be seen in Table 1 . The $\mathrm{pH}$ adjustments were done by using Orion $4 \mathrm{Star} \mathrm{pH}$ meter with a $\mathrm{pH} / \mathrm{ATC}$ plastic-body electrode. In order to provide efficient mixing, Nüve water bath shaker equipped with a controlled thermostat (Turkey) was used in batch sorption studies.

Table 1. Operating conditions for ICP-MS.

\begin{tabular}{|l|c|}
\hline Instrument Parameter & Condition \\
\hline RF power & $1550 \mathrm{~W}$ \\
\hline RF frequency & $27.12 \mathrm{MHz}$ \\
\hline RF Matching & $1.80 \mathrm{~V}$ \\
\hline Carrier gas & $1.0 \mathrm{~L} \mathrm{~min}^{-1}$ \\
\hline Collision gas & $4.5 \mathrm{~L} \mathrm{~min}^{-1}$ \\
\hline Plasma gas flow & $15 \mathrm{~L} \mathrm{~min}^{-1}$ \\
\hline Nebulizer pump & $0.1 \mathrm{rps}^{-1}$ \\
\hline Sample intake & $0.5 \mathrm{~mL} \mathrm{~min}$ \\
\hline Spray chamber temperature & $2^{\circ} \mathrm{C}$ \\
\hline Isotope measured & ${ }^{52} \mathrm{Cr}$ \\
\hline
\end{tabular}

\subsection{Sorption Studies}

An accurately weighed amount of florisil was added into $20.0 \mathrm{~mL}$ of solutions in a $50-\mathrm{mL}$ falcon tubes containing the specified concentrations of chromium ions. The mixtures were shaken in a thermostatic water bath at $25.0^{\circ} \mathrm{C}$ for a fixed period and at the end of shaking period, the contents were filtered through filter paper. The filtrate was analyzed for final chromium concentration using ICP-MS. The effects of $\mathrm{pH}$, sorbent amount, contact time and temperature on the sorption process were realized using the same methodology. The amounts of $\mathrm{Cr}(\mathrm{III})$ sorbed onto sorbent, $q_{\mathrm{e}}\left(\mathrm{mg} \mathrm{g}^{-1}\right)$, were calculated using Equation (1).

$$
q_{e}=\frac{V\left(C_{i}-C_{e}\right)}{m}
$$

where $C_{\mathrm{i}}$ and $C_{\mathrm{e}}\left(\mathrm{mg} \mathrm{L}^{-1}\right)$ are initial and equilibrium concentrations of metal ions, $m$ (g) is the weight of sorbent in the solution and $V(\mathrm{~L})$ is the volume of the solution.

\subsection{Sorption Kinetics}

Sorption kinetic studies are important since they describe the solute uptake rate which controls the residence time of sorbate at the solid-liquid interface and also provide valuable insights into the reaction pathways [15].

Pseudo-first-order (Equation 2) and pseudo-secondorder (Equation 3) models were applied in order to investigate the sorption kinetics of Cr(III) onto florisil. Moreover, the rate-limiting step of the sorbate onto the florisil was determined using the intra-particle diffusion model (Equation 4). The conformity between experimental data and the model-predicted values was expressed by the correlation coefficients $\left(\mathrm{R}^{2}\right)$. Meanwhile, the capacity values calculated from the pseudo-first and second-order models were compared with that obtained from the experimental data. The kinetic models can be presented as follows,

$$
\begin{aligned}
\frac{1}{q_{t}} & =\left(\frac{k_{1}}{q_{1}}\right)\left(\frac{1}{t}\right)+\frac{1}{q_{1}} \\
\frac{t}{q_{t}} & =\left(\frac{1}{k_{2} q_{2}^{2}}\right)+\frac{t}{q_{2}} \\
q_{t} & =k_{p} t^{1 / 2}+C
\end{aligned}
$$

where $q_{\mathrm{t}}$ is the amount of metal ion sorbed $\left(\mathrm{mg} \mathrm{g}^{-1}\right)$ at time $(t), q_{1}$ is the maximum sorption capacity $\left(\mathrm{mg} \mathrm{g}^{-1}\right)$ and $k_{1}\left(\mathrm{~min}^{-1}\right)$ is the rate constant for pseudo-first-order sorption, $q_{2}$ is the maximum sorption capacity ( $\mathrm{mg} \mathrm{g}^{-1}$ ) and $k_{2}\left(\mathrm{~g} \mathrm{mg}^{-1} \mathrm{~min}^{-1}\right)$ is the rate constant for the secondorder sorption, $C\left(\mathrm{mg} \mathrm{g}^{-1}\right)$ is the intercept and $k_{\mathrm{p}}$ is the intraparticle diffusion rate constant $\left(\mathrm{mg} \mathrm{g}^{-1} \mathrm{~min}^{-1 / 2}\right)$. From plots of $\mathrm{t} / q_{\mathrm{t}}$ versus $t$ for the second-order reactions, the $k_{2}$ and $q_{2}$ values were calculated by using the values of intercept and slope. According to the equation (4), a plot of $1 / q_{\mathrm{t}}$ versus $1 / t$ should be a straight line with a slope of $k_{1} / q_{1}$ and intercept $1 / q_{1}$, when the sorption process follows the first-order equation. The slope of the plot $q_{\mathrm{t}}$ vs $t^{1 / 2}$ yields $k_{\mathrm{p}}$ values and intercept gives $C$ values [15].

\subsection{Sorption Isotherm Models}

The sorption equilibrium was investigated by using two well-known isotherm models (Langmuir and Freundlich) to provide the fundamental physicochemical data and 
investigate the applicability of sorption process at a fixed temperature and $\mathrm{pH}$. The equilibrium conditions of the sorption process were described by utilizing the linearized equations indicated below,

$$
\begin{gathered}
\frac{C_{e}}{q_{e}}=\frac{1}{b q_{m}}+\frac{C_{e}}{q_{m}} \\
\ln q_{e}=\ln K_{F}+n_{F} \ln C_{e}
\end{gathered}
$$

here $q_{\mathrm{m}}\left(\mathrm{mg} \mathrm{g}^{-1}\right)$ and $b\left(\mathrm{~L} \mathrm{mg}^{-1}\right)$ are constants in Langmuir's equation which are referred to the maximum sorption capacity and the binding energy, respectively [16]. Also $q_{\mathrm{e}}$ and $C_{\mathrm{e}}$ parameters represent the equilibrium sorption capacity and the equilibrium concentration, respectively. Moreover $K_{\mathrm{F}}$ is the Freundlich's constant $\left(\mathrm{mg} \mathrm{g}^{-1}\right)$ and $n_{\mathrm{F}}$ is a dimensionless number in this model [17].

\subsection{Thermodynamic Parameters}

The effect of reaction temperature on the sorption of $\mathrm{Cr}$ (III) was studied at 25.0 and $40^{\circ} \mathrm{C}$ while keeping the other parameters constant $\left(20.0 \mathrm{~mL}\right.$ of $100.0 \mu \mathrm{g} \mathrm{L} \mathrm{L}^{-1}$ $\mathrm{Cr}(\mathrm{III})$ solution, $30.0 \mathrm{mg}$ sorbent, $\mathrm{pH}$ of 6.0 ). The corresponding standard Gibbs free energy change $\left(\Delta G^{\circ}\right)$, standard enthalpy change $\left(\Delta H^{\circ}\right)$, and standard entropy change $\left(\Delta S^{\circ}\right)$ were calculated utilizing the well-known equations 7-9 [18]. The Gibbs free energy of sorption was estimated from the following equation,

$$
\Delta G^{o}=-R T \ln K_{c}
$$

Standard entropy change $\left(\Delta S^{\circ}\right)$ and standard enthalpy change $\left(\Delta H^{\circ}\right)$, of sorption process can be found from van’t Hoff equation as shown below,

$$
\ln K_{c}=-\Delta H_{a d s}^{o} / R T+\Delta S^{o} / R
$$

where $R$ is the gas constant, $K_{\mathrm{c}}$ is sorption equilibrium constant computed using the following equation,

$$
K_{c}=C_{s} / C_{e}
$$

where $C_{\mathrm{s}}$ is the amount of adsorbed by sorbent, and $C_{\mathrm{e}}$ is the equilibrium concentration of ion in the solution. The plot of $\ln K_{\mathrm{c}}$ versus $1 / T$ should be linear. $\Delta H^{\circ}$ and $\Delta S^{\circ}$ were computed from the slope and intercept of van't Hoff plots of $\ln K_{\mathrm{c}}$ versus $1 / T$ [19].

\section{Results and Discussion \\ 3.1 Effect of pH}

The solution $\mathrm{pH}$ is one of the most important factors in controlling the sorption of different species by a given sorbent. The effect of $\mathrm{pH}$ on sorption of $20.0 \mathrm{~mL}$ of 100.0

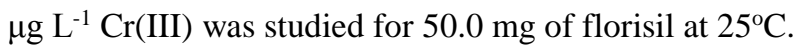
The $\mathrm{pH}$ of the solutions was adjusted within 2.0 and 10.0 and the mixtures were shaken for 120 minutes. After filtration, sorption percentage was determined. As can be seen from Figure 1, Cr(VI) was not taken up by the sorbent at any $\mathrm{pH}$ values and the quantitative (>90\%) sorption of $\mathrm{Cr}$ (III) occurred in the $\mathrm{pH}$ range of 2.0-8.0, whereas the sorption was rather low $(<50 \%)$ at $\mathrm{pH} 10.0$. According to chromium speciation diagrams, in the $\mathrm{pH}$ range of 3-8, the possible $\mathrm{Cr}$ species are $\mathrm{Cr}^{3+}, \mathrm{Cr}(\mathrm{OH})^{2+}$, $\mathrm{Cr}(\mathrm{OH})_{2}{ }^{+}$etc. [20] The sorption phenomena may be explained by the electrostatic interactions between the negatively charged sorbent surface and the positively charged chromium species. On the other hand, at $\mathrm{pH}$ values higher than 8.0, $\mathrm{Cr}$ (III) could probably be suffering from hydrolysis, forming $\mathrm{Cr}(\mathrm{OH})_{4}^{-}$and $\mathrm{Cr}(\mathrm{OH})_{3}$ species which may promote a decrease in the sorption capacity [21]. A sorption $\mathrm{pH}$ of 6.0 was selected in the subsequent experiments to be on the safe side.

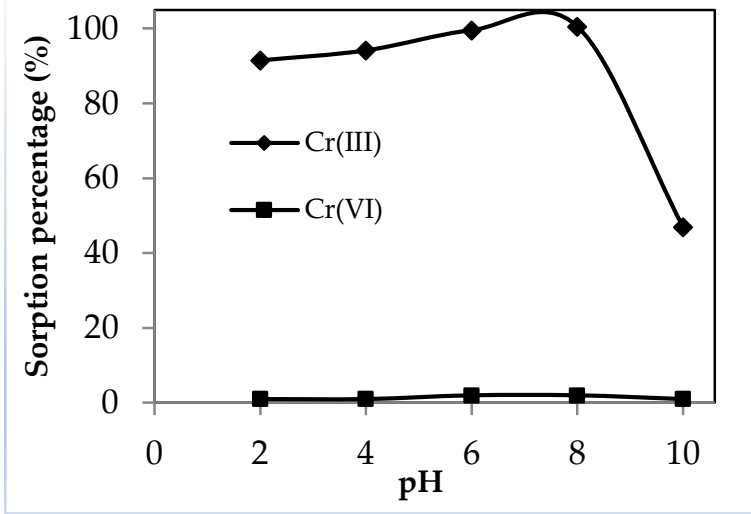

Figure 1. Effect of $\mathrm{pH}$ on the sorption of $\mathrm{Cr}(\mathrm{III})$ and $\mathrm{Cr}(\mathrm{VI})$ towards florisil sorbent (100 $\mu \mathrm{g} \mathrm{L} \mathrm{-}^{-1} \mathrm{Cr}(\mathrm{III})$ and $\mathrm{Cr}(\mathrm{VI}), 20.0 \mathrm{~mL}$ sample volume, $120.0 \mathrm{~min}$. contact time, $50.0 \mathrm{mg}$ sorbent at $25.0^{\circ} \mathrm{C}$ sorption temperature).

\subsection{Effect of Sorbent Amount}

Sorbent amount is an important factor to be optimized in order to achieve high recoveries for the removal of the analytes. In order to determine the optimum sorbent amount, sorbent amounts varying from 5.0 - $100.0 \mathrm{mg}$ were added into $20.0 \mathrm{~mL}$ of $\mathrm{Cr}$ (III) solutions and shaken for 120.0 minutes ( $\mathrm{pH}$ of 6.0). As can be seen from Figure 2 , the removal of $\mathrm{Cr}$ (III) was even high ( $\sim 80 \%)$ with a very small sorbent amount $(5.0 \mathrm{mg})$ and increased with higher sorbent amounts. For the quantitative sorption of $\mathrm{Cr}(\mathrm{III})$ ions, a sorbent amount of $30.0 \mathrm{mg}$ (sorbent amount/solution volume ratio of $1.5 \mathrm{mg} / \mathrm{mL}$ ) was used in the following studies as no further increase in sorption after a certain amount of sorbent was observed. 


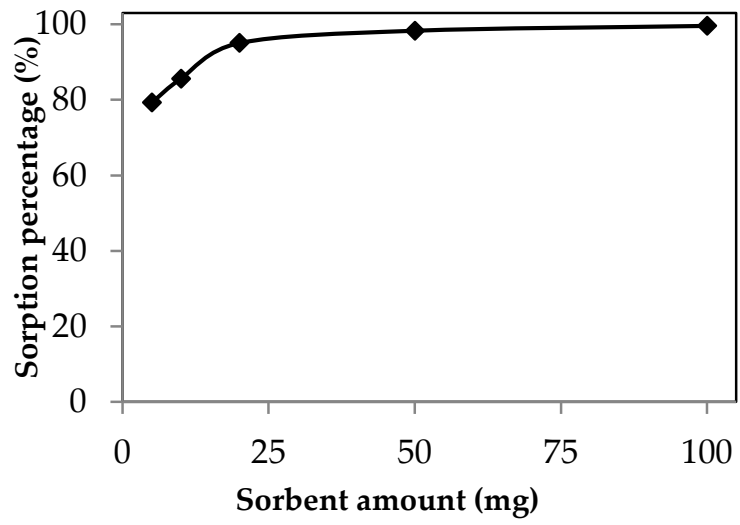

Figure 2. Effect of florisil sorbent amount on sorption (100 $\mu \mathrm{g}$ $\mathrm{L}^{-1} \mathrm{Cr}(\mathrm{III})$ solutions, $20.0 \mathrm{~mL}$ sample volume, $\mathrm{pH}$ 6.0, $120 \mathrm{~min}$. contact time, at $25^{\circ} \mathrm{C}$ sorption temperature).

\subsection{Effect of Sample Volume}

In order to explore the possibility of analytes from large volumes, the effect of sample volume on the retention of $\mathrm{Cr}(\mathrm{III})$ was also investigated. For this purpose, 20.0, 50.0, 100.0, 250.0, and $500.0 \mathrm{~mL}$ sample volumes at a constant absolute amounts of Cr(III) $(2.0 \mu \mathrm{g})$ were prepared. All the other parameters were kept constant at their respective optima. As can be seen from Figure 3, almost quantitative recoveries (85-98\%) were obtained even with a sample volume of $250.0 \mathrm{~mL}$. This provides the use of the proposed methodology with relatively large sample volumes. On the other hand, almost $50 \%$ percent sorption was obtained for $\mathrm{Cr}$ (III) for $500.0 \mathrm{~mL}$ of sample volume.

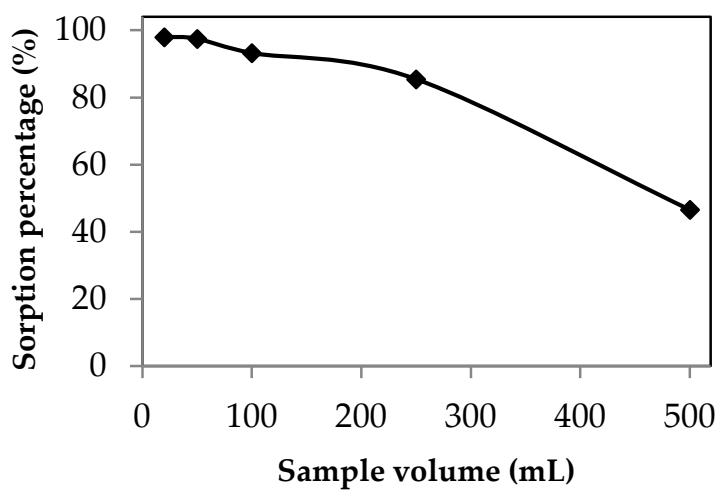

Figure 3. Effect of sample volume on sorption $(2.0 \mu \mathrm{g} \mathrm{Cr}$ (III) solutions, 30.0 sorbent amount, $\mathrm{pH}$ 6.0, $120 \mathrm{~min}$. contact time, at $25^{\circ} \mathrm{C}$ sorption temperature).

\subsection{Sorption Kinetics}

The kinetic study of sorption is important since it depicts the uptake rate of adsorbate, and controls the residual time of the whole sorption process. Figure 4a depicts the effect of contact time on the sorption of Cr(III) onto florisil. As can be seen from the figure, the sorption has increased with increasing contact time up to 60.0 minutes. After this equilibrium time, the sorption efficiency was almost constant probably due to the decrease in the diffusion rate since the sites of the sorbent are covered with $\mathrm{Cr}$ (III) ions. As a result, 60.0 minutes of a sorption time was used in the subsequent experiments. The kinetic examination of sorption process is also an important factor since the rate of sorption process influences the attainment of equilibrium in a reasonable amount of time. Therefore, the kinetics of Cr(III) sorption onto florisil was investigated to explore the sorption mechanism using the pseudo-first-order, the pseudosecond-order and intraparticle diffusion kinetic models. Plots of pseudo-first-order, pseudo-second-order and intraparticle diffusion kinetic models are shown Figures $4 \mathrm{~b}, \mathrm{c}$ and d, respectively. Table 2 shows the sorption kinetics parameters of $\mathrm{Cr}$ (III) sorption on florisil at $25^{\circ} \mathrm{C}$. As seen from the results, the correlation coefficient values $\left(\mathrm{R}^{2}\right)$ of pseudo-second-order model were higher than that of pseudo-first-order model. Moreover, when the sorption data was processed to determine whether intraparticle diffusion fits the sorption process, it was investigated that the intraparticle diffusion may not the rate-controlling step. Based on these results, it was concluded that the sorption of $\mathrm{Cr}$ (III) onto florisil was best described by pseudo-second-order model.
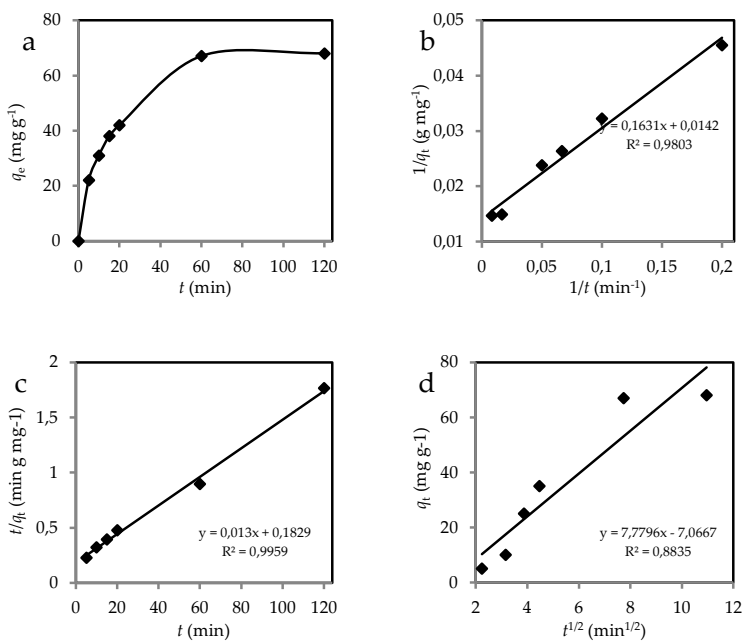

Figure 4. a) Effect of contact time on the sorption of $\operatorname{Cr}(\mathrm{III})$ towards sorbent, b) pseudo-first-order model's plot, c) pseudosecond-order model's plot and d) intraparticle diffusion model's plot. 
Table 2. Kinetic parameters of various models fitted to experimental data.

\begin{tabular}{|c|c|c|c|c|c|c|c|c|c|}
\hline \multirow{2}{*}{$\begin{array}{c}q_{\text {exp }} \\
\left(\mathrm{mg} \mathrm{g}^{-1}\right)\end{array}$} & \multicolumn{3}{|c|}{ First-order model } & \multicolumn{3}{c|}{ Second-order model } & \multicolumn{3}{c|}{ Intraparticle diffusion model } \\
\cline { 2 - 9 } & $\begin{array}{c}q_{1} \\
\left(\mathrm{mg} \mathrm{g}^{-1}\right)\end{array}$ & $\begin{array}{c}k_{1} \\
\left(\mathrm{~min}^{-1}\right)\end{array}$ & $R^{2}$ & $\begin{array}{c}q_{2} \\
\left(\mathrm{mg} \mathrm{g}^{-1}\right)\end{array}$ & $\begin{array}{c}k_{2} \\
\left(\mathrm{~g} \mathrm{mg}^{-1}\right. \\
\left.\mathrm{min}^{-1}\right)\end{array}$ & $R^{2}$ & $\begin{array}{c}C \\
\left(\mathrm{mg} \mathrm{g}^{-1}\right)\end{array}$ & $\begin{array}{c}k_{\mathrm{p}} \\
\left(\mathrm{mg} \mathrm{g}^{-1}\right.\end{array}$ & $R^{2}$ \\
$\left.\mathrm{~min}^{-1 / 2}\right)$ & 7.78 & 0.8835 \\
\hline 67.50 & 70.42 & 11.49 & 0.9803 & 76.92 & 0.0009 & 0.9959 & -7.07 & 7.78 \\
\hline
\end{tabular}

\subsection{Sorption Isotherm Models}

Sorption isotherm models represent the relationship between the amounts of adsorbate sorbed per unit mass of sorbent and the concentration of sorbate in the equilibrium solution at a given temperature. The sorption isotherm models provide information on sorption mechanisms, surface properties and affinity of a sorbent towards metal ions $[18,19]$. In order to study the sorption isotherms, the experiments were carried out with $30.0 \mathrm{mg}$ florisil sorbent and $20.0 \mathrm{~mL} \mathrm{Cr}(\mathrm{III})$ solutions with various initial concentrations between $1.0-500 \mathrm{mg} \mathrm{L}^{-1}$ at $\mathrm{pH} 6.0$ at a contact time of 60.0 minutes. The obtained results were depicted in Figure 5 and the detailed parameters of sorption isotherms are listed in Table 3. The results have indicated that the sorption of Cr(III) ions onto florisil sorbent well fitted with the Langmuir model since a higher correlation coefficient value was obtained $\left(\mathrm{R}^{2}=0.9965\right)$. In other words, the sorption process took place at the binding sites on the surface of the sorbent which is regarded as monolayer sorption. Moreover, the maximum Langmuir sorption capacity $\left(q_{\mathrm{m}}\right)$ for $\mathrm{Cr}(\mathrm{III})$ sorbed by florisil was calculated as $71.43 \mathrm{mg} \mathrm{g}^{-1}$ which was closed to the experimental data obtained ( $q_{\exp }=67.5$ $\mathrm{mg} \mathrm{g}^{-1}$ ).
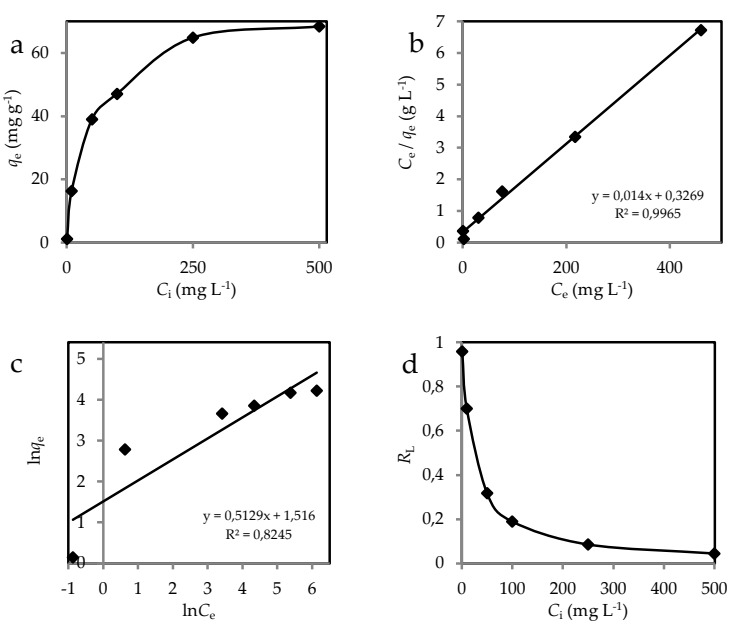

Figure 5. a) Variation of the amount of $\mathrm{Cr}$ (III) sorbed with the initial concentration of $\mathrm{Cr}(\mathrm{III})$ solution, b) Langmuir model's plot, c) Freundlich model's plot and d) Separation factors' $\left(R_{\mathrm{L}}\right)$ plot.
Table 3. Isotherm model's constants for florisil sorbent.

\begin{tabular}{|c|c|c|c|c|c|c|}
\hline \multirow{2}{*}{$\begin{array}{c}q_{\exp } \\
\left(\mathrm{mg} \mathrm{g}^{-1}\right)\end{array}$} & \multicolumn{3}{|c|}{ Langmuir model } & \multicolumn{3}{c|}{ Freundlich model } \\
\cline { 2 - 7 } & $\begin{array}{c}q_{\mathrm{m}} \\
\left(\mathrm{mg} \mathrm{g}^{-1}\right)\end{array}$ & $\begin{array}{c}b \\
\left(\mathrm{~L} \mathrm{mg}^{-1}\right)\end{array}$ & $R^{2}$ & $\begin{array}{c}K_{\mathrm{F}} \\
\left(\mathrm{mg} \mathrm{g}^{-1}\right)\end{array}$ & $n_{\mathrm{F}}$ & $R^{2}$ \\
\hline 67.50 & 71.43 & 0.043 & 0.9965 & 0.416 & 0.513 & 0.8245 \\
\hline
\end{tabular}

Additionally, the essential characteristics of the Langmuir isotherm can be expressed by a dimensionless constant separation factor, $R_{\mathrm{L}}$, which is given by Equation (10) [22].

$$
R_{L}=\frac{1}{1+b C_{i}}
$$

where $b$ is the Langmuir constant and $C_{\mathrm{i}}$ is the initial concentration of the metal ion in solution. The separation factor, $R_{\mathrm{L}}$, represent the shape of the isotherm and the nature of the sorption process as given below. The $R_{\mathrm{L}}$ value gives the nature of the process: If $R_{\mathrm{L}}>1$ unfavorable, $R_{\mathrm{L}}=1$ linear, $0<R_{\mathrm{L}}<1$ favorable and $R_{\mathrm{L}}=$ 0 irreversible. The calculated $R_{\mathrm{L}}$ values versus initial $\mathrm{Cr}$ (III) concentration are represented in Figure $5 \mathrm{~d}$. As it can be seen from this figure, the values of $R_{\mathrm{L}}$ are in the range of $0-1$ at all initial metal concentrations. These results indicate that sorption process is extremely favorable.

\subsection{Sorption Thermodynamics}

The effect of temperature on the sorption process is important since it affects the extent and rate of sorption and provides information about possible sorbate-sorbent interaction. The change in the percent sorption $\mathrm{Cr}$ (III) onto florisil was investigated for 25.0 and $400^{\circ} \mathrm{C}$ using $100.0 \mu \mathrm{g} \mathrm{L}^{-1} \mathrm{Cr}(\mathrm{III})$, at a $\mathrm{pH}$ of 6.0 , with $30.0 \mathrm{mg}$ sorbent for 60.0 minutes of contact time. As a result, a decrease ( $15 \%)$ in percent sorption value with the increase in the temperature was observed. The summary of the thermodynamic parameters are given in Table 4. The negative $\Delta G^{0}$ values increased with temperature, indicating the spontaneity of the sorption process onto florisil. The negative $\Delta H^{\circ}$ indicated the exothermic nature of the sorption process and negative values of $\Delta S^{\circ}$ (decrease in entropy) are a sign of the system becoming less random. 
Table 4. Thermodynamic parameters for the sorption Cr(III) by florisil

\begin{tabular}{|c|c|c|c|c|}
\hline$T(\mathrm{~K})$ & $K_{\mathrm{c}}$ & $\begin{array}{c}\Delta G^{0} \\
(\mathrm{~kJ} \mathrm{~mol}- \\
1\end{array}$ & $\begin{array}{c}\Delta S^{0} \\
\left(\mathrm{~kJ} \mathrm{~mol}^{-1} \mathrm{~K}^{-1}\right)\end{array}$ & $\begin{array}{c}\Delta H^{0} \\
\left(\mathrm{~kJ} \mathrm{~mol}^{-1}\right)\end{array}$ \\
\hline 298 & 79.60 & -10.85 & $-0,2067$ & $-72,46$ \\
\hline 313 & 19.60 & -7.74 & & \\
\hline
\end{tabular}

\subsection{Desorption from the Sorbent}

The possibility of quantitative desorption of $\mathrm{Cr}$ (III) from florisil was studied using several eluents namely $\mathrm{HCl}$ (0.01, 0.1, 1.0, 4.0 M), $\mathrm{HNO}_{3}(0.01,0.1,1.0,4.0 \mathrm{M})$, EDTA $\left(0.01 \mathrm{M}\right.$ ) and $\mathrm{KIO}_{3}$ (in $2.0 \mathrm{M} \mathrm{HCl}$ ). The experiments were performed using $20.0 \mathrm{~mL}$ of aqueous solution of $100.0 \mu \mathrm{g} \mathrm{mL} \mathrm{m}^{-1} \mathrm{Cr}(\mathrm{III})$ at a $\mathrm{pH}$ of 6.0 using $30.0 \mathrm{mg}$ florisil. After sorption for 60.0 minutes, the desorption of $\mathrm{Cr}$ (III) from the sorbent was performed using $20.0 \mathrm{~mL}$ of the eluent solutions. Among the eluents tried in the study, only $\mathrm{KIO}_{3}$ (in $2.0 \mathrm{M} \mathrm{HCl}$ ) was sufficient for quantitative elution of $\mathrm{Cr}$ (III) (>90\%) from the sorbent while the desorption percentage of the others varied between 5 and $70 \%$. Moreover, in order to determine enrichment factor, sorption studies were performed using variable sample volumes (20.0, 50.0, 100.0, 250.0, and $500.0 \mathrm{~mL}$ ) using an absolute amounts of $\operatorname{Cr}(\mathrm{III})(2.0 \mu \mathrm{g})$ in the solutions. After desorption with $20.0 \mathrm{~mL}$ of $\mathrm{KIO}_{3}$ (in $2.0 \mathrm{M} \mathrm{HCl}$ ), the eluates were analyzed with ICP-MS. The results demonstrated the efficiency of the method since an enrichment factor of 25 was obtained using the proposed method.

\subsection{Interference Studies}

In order to investigate the interference effects of several ions (Cd(II), Fe(III), Ni(II), Cu(II) and Pb(II)) on Cr(III) sorption, the experiments were performed in such a way that various concentrations of these ions were prepared an spiked with $\mathrm{Cr}$ (III). For this purpose, 0.1, 1.0 and 10.0 $\mathrm{mg} \mathrm{L}^{-1}$ concentrations of above mentioned ions were prepared in $20.0 \mathrm{~mL}$ of $0.1 \mathrm{mg} \mathrm{L}^{-1} \mathrm{Cr}$ (III) and the sorption behavior of the sorbent towards $\mathrm{Cr}$ (III) in the presence of towards listed ions were investigated. Any effect causing at least $15 \%$ decrease in sorption was considered as interference. As can be seen from Table 5, for all three investigated concentrations of $\mathrm{Cd}(\mathrm{II}), \mathrm{Fe}(\mathrm{III}), \mathrm{Ni}(\mathrm{II})$, $\mathrm{Cu}(\mathrm{II})$ and $\mathrm{Pb}(\mathrm{II})$, no remarkable interference effect on Cr(III) sorption was observed.

Table 5. Summary of interference study.

\begin{tabular}{|c|c|c|}
\hline Ion & $\begin{array}{c}\text { Concentration } \\
\left(\mathrm{mg} \mathrm{L}^{-1}\right)\end{array}$ & $\begin{array}{c}\text { Cr (III) } \\
\text { Sorption } \\
\text { percentage (\%) }\end{array}$ \\
\hline $\mathrm{Cd}$ & 0.10 & 99 \\
\hline & 1.00 & 99 \\
\hline & 10.0 & 98 \\
\hline $\mathrm{Fe}$ & 0.10 & 99 \\
\hline & 1.00 & 98 \\
\hline & 10.0 & 98 \\
\hline
\end{tabular}

\begin{tabular}{|c|c|c|}
\hline $\mathrm{Ni}$ & 0.10 & 99 \\
\hline & 1.00 & 97 \\
\hline & 10.0 & 97 \\
\hline $\mathrm{Cu}$ & 0.10 & 98 \\
\hline & 1.00 & 98 \\
\hline $\mathrm{Pb}$ & 10.0 & 97 \\
\hline & 0.10 & 99 \\
\hline & 1.00 & 98 \\
\hline & 10.0 & 97 \\
\hline
\end{tabular}

\subsection{Real Sample Analysis}

To evaluate the accuracy and applicability of the proposed method, sorption/desorption experiments were performed with ultra-pure, tap, bottled drinking and waste water samples. The water samples were filtered through MFS membrane filter (pore size $0.45 \mu \mathrm{m}$ ) and analyzed as soon as possible after sampling. The water samples were spiked with various amounts of $\mathrm{Cr}$ (III) (10 $\mu \mathrm{g} \mathrm{L}^{-1}$ ) and the analysis was carried out under the optimized conditions described above. Blank samples were also prepared in the same manner and analyzed by ICP-MS and all were below the detection limit. The percentage sorption values were obtained as $94.2( \pm 0.8)$, $88.1( \pm 1.2), 86.4( \pm 2.3)$ and $75.6( \pm 3.4)$ for ultrapure, bottled drinking, tap and waste water samples, respectively. The results have indicated that the proposed procedure is suitable for the determination of $\mathrm{Cr}$ (III) ions and has potential for application in water remediation studies.

\subsection{Comparison with Other Sorbents}

Table 6 summarizes the comparison of sorption of $\mathrm{Cr}$ (III) by florisil and other sorbents used in literature [23-31]. It can be seen that in most of the cases, $\mathrm{Cr}$ (III) uptake value by florisil is highly competitive and the sorbent has the less, comparable or better sorption capacity values than those reported previously. The high sorption values with good relative standard deviation values are some of the advantages of the proposed method. Consequently it can be concluded that florisil is a promising sorbent for the removal of $\mathrm{Cr}(\mathrm{III})$ ions in waters.

Table 6. Comparison of sorbent capacities for Cr(III) sorption.

\begin{tabular}{|l|c|c|}
\hline \multicolumn{1}{|c|}{ Sorbent } & $q_{m}\left(\mathrm{mg} \mathrm{g}^{-1}\right)$ & Reference \\
\hline $\begin{array}{l}\text { Modified peanut } \\
\text { sawdust }\end{array}$ & 7.7 & {$[23]$} \\
\hline $\begin{array}{l}\text { Yellow passion- } \\
\text { fruit shell }\end{array}$ & 85.1 & {$[24]$} \\
\hline Animal bones & 60.9 & {$[25]$} \\
\hline $\begin{array}{l}\text { Diatomite treated } \\
\text { with } \\
\text { microemulsion }\end{array}$ & 11.55 & {$[26]$} \\
\hline $\begin{array}{l}\text { Agave lechugilla } \\
\text { biomass }\end{array}$ & 14.2 & {$[27]$} \\
\hline Eucalyptus bark & 45.0 & {$[28]$} \\
\hline
\end{tabular}




\begin{tabular}{|l|c|c|}
\hline $\begin{array}{l}\text { Turkish brown } \\
\text { coal }\end{array}$ & 13.52 & {$[29]$} \\
\hline Lewatit S 100 & 20.28 & {$[30]$} \\
\hline Activated carbon & 39.56 & {$[31]$} \\
\hline Florisil & 67.5 & This work \\
\hline
\end{tabular}

8. Rengaraj, S, Yeon, K.H, Moon, S.H, Removal of chromium from water and wastewater by ion exchange resins, Journal of Hazardous Materials, 2001, B87, 273-287.

9. Singh, P, Nagendran, R.A, Comparative study of sorption of chromium (III) onto chitin and chitosan, Applied Water Science, 2016, 6, 199-204.

\section{Conclusions}

This work has demonstrated that florisil can be used as an effective sorbent for the removal of $\mathrm{Cr}(\mathrm{III})$ ions from aqueous solutions. The effects of several factors such as $\mathrm{pH}$, sorbent amount, contact time, and temperature on the sorption of $\mathrm{Cr}(\mathrm{III})$ ions were investigated. Equilibrium data best fitted to Langmuir isotherm model, indicating the monolayer coverage of the $\mathrm{Cr}(\mathrm{III})$ ions onto florisil. Pseudo-second-order kinetic model provided the best correlation with the experimental data. Thermodynamic parameters indicated that, under the studied temperature range, the sorption of $\mathrm{Cr}$ (III) by florisil was feasible and had a spontaneous and exothermic nature. The desorption form the sorbent was realized with $\mathrm{KIO}_{3}$ (in $2.0 \mathrm{M} \mathrm{HCl}$ ) The applicability of the proposed method tested with ultra pure, tap, bottled drinking and waste water samples and it was found that the proposed procedure is suitable for the determination of $\mathrm{Cr}(\mathrm{III})$ ions in real samples. Overall, this study suggests that florisil is a promising sorbent for the removal of $\mathrm{Cr}(\mathrm{III})$ ions from aqueous solutions.

\section{References}

1. Fengying, Z, Xiaofeng, L, Huiwu, Y, Shunxing, L, Xuguang, H, Visible-light photoreduction, adsorption, matrix conversion andmembrane separation for ultrasensitive chromium determination innatural water by X-ray fluorescence, Sensors and Actuators B, . 2016, 226, 500-505.

2. Iga, K, Halina, P.M, Bozena, D, Determination of chromium in biological materials by radiochemical neutron activation analysis (RNAA) using manganese dioxide, Journal of Radioanalytical and Nuclear Chemistry, 2016, 310, 559-564.

3. Manzoori, J.L, Mohammed, H, Shemirani, F, Chromium speciation by a surfactant-coated alumina microcolumn using electrotherma atomic absorption spectrometry, Talanta, 1994, 42, 1151-1155.

4. Jiang, W, Cai, Q, Xu, W, Yang, M, Cai, Y, Dionysiou, D.D O'Shea, K.E, Cr(VI) adsorption and reduction by humic acid coated on magnetite, Environmental Science and Technology, 2014, 48, 80788085.

5. Li, S.X, Zheng, F.Y, Hong, H.S, Deng, N.S, Lin, L.X, Influence of marine phytoplankton, transition metals and sunlight on the species distribution of chromium in surface seawater, Marine Environmental Research, 2009, 67, 199-206.

6. Chen, S, Zhu, S, He, Y, Lu, D, Speciation of chromium and its distribution in tea leaves and tea infusion using titanium dioxide nanotubes packed micro-column coupled with inductively coupled plasma mass spectrometry, Food Chemistry, 2014, 150, 254-259.

7. Taa, N, Benyahya, M, Chaouch, M, Using a bio-flocculent in the process of coagulation flocculation for optimizing the chromium removal from the polluted water, Journal of Materials and Environmental Science, 2016, 7 (5), 1581-1588.

10. Narayana, S.L, Reddy, S.A.N, Subbarao, Y, Inseong, H, Reddy, A.V, A simple and highly sensitive spectrophotometric determination of $\mathrm{Cr}(\mathrm{VI})$ in food samples by using 3,4dihydroxybenzaldehydeisonicotinoylhydrazone (3,4-DHBINH), Food Chemistry, 2010, 121(4), 1269-1273.

11. Ramakrishnaiah, C.R, Prathima, B, Hexavalent Chromium Removal by Chemical Precipitation Method: A Comparative Study, International Journal of Environmental Research and Development, 2011, 1 (1), 41-49.

12. Bailey, S.E, Olin, T.J, Bricka, R.M, Adrian, D.D, A review of potentially low-cost sorbents for heavy metals, Water Research. 1999, 33 (11), 2469-2479.

13. Liu, Y, Zhu, L, Sun, X, Chen, J, Luo, F. Silica materials doped with bifunctional ionic liquid extractants for Yttrium extraction, Industria and. Engineering Chemistry Research, 2009, 48, 7308-7313.

14. Zhang, A, Wang, W. Chai, Z. Kuraoka, E, Modification of a novel macroporous Silica-based Crown ether impregnated polymeric composite with 1-dodecanol and its adsorption for some fission and non-fission product contained in high level liquid waste, European. Polymer Journal, 2008, 44, 3899-3907.

15. Azizian, S, Kinetic models of sorption: A theoretical analysis. Journal of Colloid and Interface Science, 2004, 276(1), 47-52.

16. Saeed, K, Haider, S, Oh, T.J, Park, S.Y, Preparation of amidoximemodified polyacrylonitrile (PAN-oxime) nanofibers and their applications to metal ions adsorption, Journal of Membrane Science, 2008, 322(2), 400-405.

17. Vuković, G.D, Marinković, A.D, Čolić, M, Ristić, M.Đ, Aleksić, R, Perić-Grujić, A.A, Uskoković, P.S, Removal of cadmium from aqueous solutions by oxidized and ethylenediamine-functionalized multi-walled carbon nanotubes, Chemical Engineering Journal. 2010, 157(1), 238-248.

18. Atkins, P, de Paula, J, Physical Chemistry, Oxford University Press, New York, 2006; pp 156.

19. Seki, Y, Yurdakoç, K, Sorption of Promethazine hydrochloride with KSF Montmorillonite, Adsorption, 2006, 12, 89-100.

20. Zouboulis, A.I, Kydros, K.A, Matis, K.A, Removal of hexavalent chromium anions from solutions by pyrite fines, Water Research, 1995 29/7, 1755-1760.

21. Jacques, R.A, Bernardi, R, Caovila, M, Lima, E.C, Pavan, F.A, Vaghetti, J.C.P, Airoldi, C, Removal of Cu(II), Fe(III), and Cr(III) from Aqueous Solution by Aniline Grafted Silica Gel, Separation Science and Technology, 2007, 42, 591-609.

22. Hall, K.R, Eagleton, L.C, Acrivos, A, Vermeulen, T, Pore and Solid Diffusion Kinetics in Fixed- Bed Adsorption under Constant Pattern Conditions. Industrial and Engineering Chemistry Fundamentals, 1966, 5, 212-223.

23. Li, Q, Zhai, J, Zhang, W, Wang, M, Zhou, J, Kinetic studies of adsorption of $\mathrm{Pb}(\mathrm{II}), \mathrm{Cr}(\mathrm{III})$ and $\mathrm{Cu}(\mathrm{II})$ from aqueous solution by sawdust and modified peanut husk, Journal of Hazardeous Materials, 2007, 141, 163-167. 
Celal Bayar University Journal of Science

Volume 13, Issue 3, p 635-642

24. Jacques, R.A, Limaa, E.C, Dias, S.L.P, Mazzocato, A.C, Pavan, F.A, Yellow 561 passion-fruit shell as biosorbent to remove $\mathrm{Cr}$ (III) and $\mathrm{Pb}$ (II) from aqueous 562 solution, Separation and. Purification Technology, 2007, 57, 193-198.

25. Chojnacka, K, Equilibrium and kinetic modelling of chromium(III) sorption by animal bones, Chemosphere. 2005, 59, 315-320.

26. De castro dantas, T.N, Dantas neto, A.A, De A. Moura, M.C.P, Removal of chromium from aqueous solutions by diatomite treated with microemulsion, Water Research, 2001, 35, 2219-2224.

27. Romero-Gonzalez, J, Peralta-Videa, J.R. Rodriguez, E, Delgado, M, Gardea-Torresdey, J.L, Potential of Agave lechuguilla biomass for $\mathrm{Cr}(\mathrm{III})$ removal from aqueous solutions: thermodynamic studies, Bioresource Technology, 2006, 97(1), 178-82.
A. Erdem Yayayürük

28. Sarin, V., Pant, K.K. Removal of chromium from industrial waste by using eucalyptus bark, Bioresource Technology, 2006, 97(1), 15-20.

29. Gode, F, Pehlivan, E, Adsorption of $\mathrm{Cr}(\mathrm{III})$ ions by Turkish brown coals, Fuel Processing Technology, 2005, 86, 875-884.

30. Gode, F., Pehlivan, E. Removal of chromium(III) from aqueous solutions using Lewatit S 100: The effect of $\mathrm{pH}$, time, metal concentration and temperature, Journal of Hazardeous Materials, 2006, $136,330-337$.

31. Mohan, D, Pittman, C.U, Steele Jr, P.H, Pyrolysis of wood/ biomass for bio-oil: a critical review, Energy Fuels. 2006, 20, 848-889. 